\title{
Generation and Characterization of an scFv Directed against Site II of Rabies Glycoprotein
}

\author{
Shukra M. Aavula, Sridevi V. Nimmagadda, Neelakantam Biradhar, Samuel Sula, \\ Dev Chandran, Rajendra Lingala, and Srinivasan Alwar Villuppanoor \\ Research and Development Center, Indian Immunologicals Limited, Rakshapuram, Gachibowli, Hyderabad 500032, India \\ Correspondence should be addressed to Srinivasan Alwar Villuppanoor, srini@indimmune.com
}

Received 1 June 2011; Revised 4 August 2011; Accepted 10 August 2011

Academic Editor: Ricardo Kratje

Copyright (C) 2011 Shukra M. Aavula et al. This is an open access article distributed under the Creative Commons Attribution License, which permits unrestricted use, distribution, and reproduction in any medium, provided the original work is properly cited.

Recombinant antibody phage display technology is a vital tool that facilitates identification of specific binding molecules to a target enabling the rapid generation and selection of high affinity, fully human, or mouse antibody product candidates essentially directed towards disease target appropriate for antibody therapy. In this study, a recombinant single-chain Fv antibody fragment $(\mathrm{scFv})$ A11 was isolated from immune spleen cells obtained from mice immunized with inactivated rabies virus (Pasteur strain) using standard methodology and was characterized for its specificity towards the rabies virus glycoprotein. Epitope mapping using peptide libraries and truncated glycoprotein polypeptides suggested that A11 bound to the antigenic site II of rabies glycoprotein against which a majority of rabies virus neutralizing antibodies are directed. The use of the above technology could, therefore, allow development of scFvs with different specificities against the rabies glycoprotein as an alternative to the more cumbersome protocols used for the development of monoclonal antibodies.

\section{Introduction}

Rabies is a viral, zoonotic, and invariably fatal neuroinvasive disease of humans caused by the bite of rabid animal. More than 55,000 deaths occur annually worldwide in spite of the use of postexposure therapy preventive measures, making rabies one of the major causes of human mortality despite significant scientific progress $[1,2]$. Administration of antivirus immunoglobulins includes the use of both human and equine antirabies immunoglobulins along with vaccination and is the only strategy recommended by WHO for the postexposure prophylactic treatment of rabies [3]. Most of these immunoglobulins are plasma-derived, polyclonal products obtained from human and animal donors vaccinated against rabies which can be produced in limited amounts and suffer from potential drawbacks such as batch-to-batch variation and the risk of contamination from other pathogens $[4,5]$.

Several conventional monoclonal antibodies (MAbs) have been generated against different viruses [6] and their utilization tends to be limited in clinical applications because of possible viral contamination and high cost involved in MAb preparations. To overcome these problems, generation of single chain antibody fragments $(\mathrm{scFv})$ through phage display technology has been utilized as the methodology of choice [7-9]. Use of phage display technology as a powerful in vitro tool for production of therapeutically important antibodies against viral pathogens on the surface of bacteriophage provides an efficient method for isolation and screening of a diverse set of human and nonhuman antibodies from immunized or naïve volunteers against various infectious diseases. These antibodies have the potential of being used as immunoprophylactic/therapeutics against different disease-causing agents [10-15].

In the present study, an immune scFv library was constructed using RNA isolated from splenocytes of mice immunized with an inactivated rabies vaccine. Specific mouse scFv fragment was affinity selected from this library using inactivated rabies virus. The selected scFv A11 was shown to recognize an epitope on rabies glycoprotein (GP) antigenic site II using immune phage display library, which was further 
confirmed through its reactivity to truncated polypeptides of PV GP containing the site.

\section{Material and Methods}

2.1. Antigens, Antibodies, and Animals. Inactivated Pasteur virus rabies vaccine (AbhayRab) and purified rabies virus were obtained from Human Biologicals Institute, Ooty, India. Chikungunya antigen and its polyclonal antibodies, hepatitis A antigen and its polyclonal antibodies were procured from virology laboratory, Indian Immunologicals limited (IIL). Hepatitis B surface antigen and its monoclonal antibody (1F6) were obtained from hybridoma laboratory, IIL. Splenocytes were obtained from BALB/c mice immunized with Abhayrab (Pasteur strain); purified native glycoproteins from Pasteur virus (PV GP) were obtained from the hybridoma Laboratory, IIL, for construction of immune antibody phage display library.

2.2. Bacterial Strains, Vectors, and Chemicals. The bacterial strains used for protein overexpression in E. coli BL21(DE3), M13K07 helper phage for recombinant phage production, and all molecular biology reagents were purchased from invitrogen (Carlsbad, USA). The phagemid vector pCANTAB 5E used for cloning and expression of the scFvs on phage coat protein (pIII) was kindly provided by Dr. Sandra Saptas (CSIRO, Australia). The bacterial expression vector pET 20b was purchased from Novagen (Madison, USA). The plasmid mini-prep kit for isolation of plasmid, gel extraction kit for extraction of DNA, PCR purification kit, HiFi Taq DNA polymerase, PCR reagents, and Ni-NTA agarose used for the purification of His- tagged proteins were purchased from Qiagen (Hilden, Germany). The bacterial strain (E. coli TG1) used for the propagation of phagemid vector $\mathrm{PCANTAB} 5 \mathrm{E}$ was purchased from Stratagene, USA. Nuclease-free water and T4 DNA Ligase were purchased from GeNei, India. Glutathione agarose used for purification of GST tagged proteins and all other fine chemicals used were purchased from Sigma (USA).

2.3. Isolation of Total RNA and cDNA Synthesis. Total RNA was isolated from about $10 \times 10^{6}$ spleen cells collected from immunized mice using TRIzol reagent (Invitrogen) and resuspended in nuclease-free water. RNA was quantified by Biophotometer (Eppendorf, USA) and was subjected to cDNA synthesis using random hexamers and Thermoscript reverse transcriptase (RT)-PCR kit (Invitrogen) according to the manufacturer's instructions. The cDNA was stored at $-20^{\circ} \mathrm{C}$ until further use.

2.4. PCR Amplification of Heavy and Light Chain Variable Genes. PCR reaction was set up in a total volume of $50 \mu \mathrm{L}$ containing $5 \mu \mathrm{L}$ of cDNA, $5 \mu \mathrm{L}$ of $10 \mathrm{x}$ HiFi Taq DNA polymerase reaction buffer, $1 \mu \mathrm{L}$ of $10 \mathrm{mM}$ dNTP's, $1 \mu \mathrm{L}$ $(10 \mathrm{pmol} / \mu \mathrm{L})$ of each forward and reverse universal, degenerate primer (synthesized by MWG, India) (Table 1) [16], and 1.25 units of HiFi Taq DNA polymerase enzyme. After chilling the reaction mix on ice, it was transferred to a master cycler (Eppendorf) and cycled 7 times for $60 \mathrm{sec}$ at $92^{\circ} \mathrm{C}$, $30 \mathrm{sec}$ at $63^{\circ} \mathrm{C}, 50 \mathrm{sec}$ at $58^{\circ} \mathrm{C}$, and $60 \mathrm{sec}$ at $68^{\circ} \mathrm{C}$ followed by $60 \mathrm{sec}$ at $92^{\circ} \mathrm{C}, 60 \mathrm{sec}$ at $63^{\circ} \mathrm{C}$, and $60 \mathrm{sec}$ at $68^{\circ} \mathrm{C}$ for 23 cycles. Finally the extension cycle was increased to $10 \mathrm{~min}$ at $68^{\circ} \mathrm{C}$. Amplifications were repeated several times, and the final variable light chain $(\mathrm{VL})$ and variable heavy chain $(\mathrm{VH})$ products were pooled and gel purified.

\subsection{Assembly of VH and VL and Cloning into Phagemid} Vector. Variable domains were amplified as described above, gel purified, and assembled by a linker $\left(\mathrm{Gly}_{4} \mathrm{Ser}\right)_{3}$ using splicing by overlap extension polymerase chain reaction (SOE PCR) with VL forward and VH reverse primers (Table 1). Purified VH and VL were used in PCR for 14 cycles in the absence of primers. The amplified PCR product was reused as the template for amplifying $\left(94^{\circ} \mathrm{C}\right.$ for $60 \mathrm{sec}$, $63^{\circ} \mathrm{C}$ for $60 \mathrm{sec}, 68^{\circ} \mathrm{C}$ for $2 \mathrm{~min}, 34$ cycles) $\mathrm{scFv}$ which yielded a product of size $\sim 750$ bp using forward light chain primer (with NcoI site) and reverse heavy chain primer (with NotI site) for 34 cycles. The PCR product containing the amplified $\mathrm{scFv}$ was gel purified by gel extraction kit and cloned into PCANTAB 5E vector, which was double, digested with $\mathrm{NcoI}$ and NotI restriction enzymes according to the manufacturer's instructions (New England Biolabs, MA, USA). The digested products were further purified using a PCR purification kit, and $\sim 98 \mathrm{ng}$ of the digested $\mathrm{scFv}$ fragment was ligated into $\sim 100 \mathrm{ng}$ of digested phagemid vector (pCANTAB 5E) in a total volume of $20 \mu \mathrm{L}$ using T4 DNA ligase. The ligated product was electroporated into electrocompetant E. coli TG1 cells (Stratagene, USA, transformation efficiency of $1 \times 10^{9} / \mu \mathrm{g}$ of DNA) using an electroporator (Gene pulser Xcell, Bio-Rad, USA), and the transformed bacteria were plated on 2xYT agar.

2.6. Preparation of Phage Library. The resultant lawn of bacterial cells that was obtained after transformation on selective antibiotic media were scraped off the agar plates into $15 \mathrm{~mL} 2 \mathrm{xYT}$ media (2x Yeast extract, Tryptone) and stored at $-70^{\circ} \mathrm{C}$ in aliquots of $1 \mathrm{~mL}$ containing $20 \%$ glycerol. An aliquot was thawed and diluted with $9 \mathrm{~mL}$ of $2 \mathrm{xYT}$ containing $50 \mu \mathrm{g} / \mathrm{mL}$ of ampicillin and $2 \%$ glucose $(2 x Y T-$ $A G)$. These bacterial cells were infected with $6 \times 10^{10}$ plaque forming units (pfu) of M13K07 (Invitrogen) and the infected bacteria were incubated in an orbital shaker at $37^{\circ} \mathrm{C}$ for $2 \mathrm{~h}$. The cells were collected by centrifugation at $5000 \mathrm{rpm}$ for $10 \mathrm{~min}$ and resuspended in $10 \mathrm{~mL}$ of $2 \mathrm{xYT}$ containing $100 \mu \mathrm{g} / \mathrm{mL}$ of ampicillin and $50 \mu \mathrm{g} / \mathrm{mL}$ of kanamycin. The culture were grown overnight at $37^{\circ} \mathrm{C}$ before harvesting. The supernatant-containing phages were filtered through a $0.45 \mu \mathrm{m}$ filter and concentrated by precipitation with $1 / 5$ th volume polyethylene glycol solution (20\% PEG 6000, $2.5 \mathrm{M} \mathrm{NaCl})$ for $1 \mathrm{~h}$ on ice. The precipitated phagemids were centrifuged $\left(20 \mathrm{~min}, 6000 \times \mathrm{g}, 4^{\circ} \mathrm{C}\right)$ and resuspended in phosphate-buffered saline (PBS). Following another brief centrifugation at $4^{\circ} \mathrm{C}$ for $5 \mathrm{~min}$ at $13000 \times \mathrm{g}$, the cellular debris was removed. The concentration of the infectious phage particles was determined by infecting log phase E. coli strain TG1 cells with serially diluted phages ranging from $10^{2}$ 
TABle 1: cmd Primers used for PCR of VH and VL regions and SOE PCR for construction of scFv.

\begin{tabular}{|c|c|}
\hline \multicolumn{2}{|r|}{ Variable light chain forward primers } \\
\hline LB1 & GCCATGGCGGA(CT)ATCCAGCTGACTCAGCC \\
\hline LB2 & GCCATGGCGGA(CT)ATTGTTCTC(AT)CCCAGTC \\
\hline LB3 & GCCATGGCGGA(CT)ATTGTG(AC)T(AC)ACTCAGTC \\
\hline LB4 & GCCATGGCGGA(CT)ATTGTG(CT)T(AG)ACACAGTC \\
\hline LB5 & GCCATGGCGGA(CT)ATTGT(AG)ATGAC(AC)CAGTC \\
\hline LB6 & GCCATGGCGGA(CT)ATT(AC)AGAT(AG)A(AC)CCAGTC \\
\hline LB7 & GCCATGGCGGA(CT)ATTCAGATGA(CT)(AGT)CAGTC \\
\hline LB8 & GCCATGGCGGA(CT)AT(CT)CAGATGACACAGAC \\
\hline LB9 & GCCATGGCGGA(CT)ATTGTTCTCA(AT)CCAGTC \\
\hline LB10 & GCCATGGCGGA(CT)ATTG(AT)GCT(GC)ACCCAATC \\
\hline LB11 & GCCATGGCGGA(CT)ATT(GC)T(AG)ATGACCCA(AG)TC \\
\hline LB12 & GCCATGGCGGA(CT)(AG)TT(GT)TGATGACCCA(AG)AC \\
\hline LB13 & GCCATGGCGGA(CT)ATTGTGATGAC(GCT)CAG(GT)C \\
\hline LB14 & GCCATGGCGGA(CT)ATTGTGATAAC(CT)CAGGA \\
\hline LB15 & GCCATGGCGGA(CT)ATTGTGATGACCCAG(AT)T \\
\hline LB16 & GCCATGGCGGA(CT)ATTGTGATGACACAACC \\
\hline LB17 & GCCATGGCGGA(CT)ATTTTGCTGACTCAGTC \\
\hline \multicolumn{2}{|r|}{ Variable light chain reverse primers } \\
\hline LF1 & GGAGCCGCCGCCGCCAGAACCACCACCACCAGAACCACCACCACCACGTTTGATTTCCAGCTTGG \\
\hline LF2 & GGAGCCGCCGCCGCCAGAACCACCACCACCAGAACCACCACCACCACGTTTTATTTCCAGCTTGG \\
\hline LF4 & GGAGCCGCCGCCGCCAGAACCACCACCACCAGAACCACCACCACCACGTTTTATTTCCAACTTTG \\
\hline LF5 & GGAGCCGCCGCCGCCAGAACCACCACCACCAGAACCACCACCACCACGTTTCAGCTCCAGCTTGG \\
\hline \multicolumn{2}{|r|}{ Variable heavy chain forward primers } \\
\hline HB1 & GGCGGCGGCGGCTCCGGTGGTGGTGA(GT)GT(AG)(AC)AGCTTCAGGAGTC \\
\hline HB2 & GGCGGCGGCGGCTCCGGTGGTGGTGAGGT(GCT)CAGCT(GCT)CAGCAGTC \\
\hline HB3 & GGCGGCGGCGGCTCCGGTGGTGGTCAGGTGCAGCTGAAG(GC)A(GC)TC \\
\hline HB4 & GGCGGCGGCGGCTCCGGTGGTGGTGAGGTCCA(AG)CTGCAACA(AG)TC \\
\hline HB5 & GGCGGCGGCGGCTCCGGTGGTGGTCAGGT(CT)CAGCT(GCT)CAGCA(AG)TC \\
\hline HB6 & GGCGGCGGCGGCTCCGGTGGTGGTCAGGT(CT)CA(AG)CTGCAGCAGTC \\
\hline HB7 & GGCGGCGGCGGCTCCGGTGGTGGTCAGGTCCACGTGAAGCAGTC \\
\hline HB8 & GGCGGCGGCGGCTCCGGTGGTGGTGAGGTGAA(GC)(GC)TGGTGGAATC \\
\hline HB9 & GGCGGCGGCGGCTCCGGTGGTGGTGA(AGC)GTGA(AT)G(CT)TGGTGGAGTC \\
\hline HB10 & GGCGGCGGCGGCTCCGGTGGTGGTGAGGTGCAG(GC)(GT)GGTGGAGTC \\
\hline HB11 & GGCGGCGGCGGCTCCGGTGGTGGTGA(GT)GTGCA(AC)CTGGTGGAGTC \\
\hline HB12 & GGCGGCGGCGGCTCCGGTGGTGGTGAGGTGAAGCTGATGGA(AG)TC \\
\hline HB13 & GGCGGCGGCGGCTCCGGTGGTGGTGAGGTGCA(AG)CTTGTTGAGTC \\
\hline HB14 & GGCGGCGGCGGCTCCGGTGGTGGTGA(AG)GT(AG)AAGCTTCTCGAGTC \\
\hline HB15 & GGCGGCGGCGGCTCCGGTGGTGGTGAAGTGAA(AG)(GC)TTGAGGAGTC \\
\hline HB16 & GGCGGCGGCGGCTCCGGTGGTGGTCAGGTTACTCT(AG)AAAG(AT)GT(GC)TG \\
\hline HB17 & GGCGGCGGCGGCTCCGGTGGTGGTCAGGTCCAACT(AGC)CAGCA(AG)CC \\
\hline HB18 & GGCGGCGGCGGCTCCGGTGGTGGTGATGTGAACTTGGAAGTGTC \\
\hline HB19 & GGCGGCGGCGGCTCCGGTGGTGGTGAGGTGAAGGTCATCGAGTC \\
\hline \multicolumn{2}{|r|}{ Variable heavy chain reverse primers } \\
\hline HF1 & ATGCGCGGCCGCCGAGGAAACGGTGACCGTGGT \\
\hline HF2 & ATGCGCGGCCGCCGAGGAGACTGTGAGAGTGGT \\
\hline HF3 & ATGCGCGGCCGCCGCAGAGACAGTGACCAGAGT \\
\hline HF4 & ATGCGCGGCCGCCGAGGAGACGGTGACTGAGGT \\
\hline
\end{tabular}


to $10^{8}$, incubated in an orbital shaker at $37^{\circ} \mathrm{C}$ for $10 \mathrm{~min}$ and plated on 2xYT-AG agar plates. The phage stocks were stored at $4^{\circ} \mathrm{C}$ until use.

2.7. Biopanning of Phage Display Library against PV GP. Maxisorp Immunotube was (Nunc, Denmark) coated overnight at $4^{\circ} \mathrm{C}$ with PV GP diluted in $50 \mathrm{mM}$ of sodium carbonate-bicarbonate buffer, $\mathrm{pH}$ 9.6. After washing the tube 4 times with phosphate-buffered saline containing $0.05 \%$ Tween-20 (PBS-T), blocking was done with $1 \%$ bovine gelatin in PBS-T (1\% BGPBS-T) and incubated at $37^{\circ} \mathrm{C}$ for $2 \mathrm{~h}$. The tube was washed as mentioned above and incubated with titrated phages at $37^{\circ} \mathrm{C}$ for $2 \mathrm{~h}$. Finally the tube was washed with PBS-T 10 times followed by 10 washes with PBS. Log phase E. coli TG1 cells were added to the tubes and incubated at $37^{\circ} \mathrm{C}$ to allow infection by bound phages. Infected culture was twofold serially diluted and plated on 2xYT-AG agar plates to determine the titer of phage. The remaining culture was plated and incubated at $37^{\circ} \mathrm{C}$ for overnight. The cells were scraped and infected with helper phage M13K07 and subjected to an additional rounds of panning. Further panning was done for selection of high affinity phages with higher stringency using higher concentrations of Tween-20 that ranged from $0.05 \%$ to $0.1 \%$ and also the number of washes from 10 to 20 times.

2.8. Screening Specific Binding Clones by Phage ELISA. ELISA was performed to check the binding ability of phage to rabies virus as described by Clackson et al. [17]. Individual colonies after third round of biopanning were inoculated into $100 \mu \mathrm{L}$ of $2 \mathrm{xYT}$ containing $100 \mu \mathrm{g} / \mathrm{mL}$ ampicillin and $2 \%$ glucose $(2 \mathrm{xYT}-\mathrm{AG})$ and incubated in an orbital shaker at $37^{\circ} \mathrm{C}$ for overnight. $10 \mu \mathrm{L}$ was subcultured to $100 \mu \mathrm{L} /$ well of $2 \mathrm{xYT}$ AG media and incubated in an orbital shaker at $37^{\circ} \mathrm{C}$ till they reached an $\mathrm{O}_{0} \mathrm{D}_{600}$ of 0.6 . M13K07 helper phage at a concentration of $2.5 \times 10^{10} \mathrm{pfu} / \mathrm{mL}$ was added and the cultures were further incubated in an orbital shaker for $2 \mathrm{~h}$ and then centrifuged at $4000 \mathrm{rpm}$ for $20 \mathrm{~min}$. The bacterial pellet was resuspended in $2 \mathrm{xYT}$ containing $100 \mu \mathrm{g} / \mathrm{mL}$ ampicillin, $50 \mu \mathrm{g} / \mathrm{mL}$ kanamycin, and $2 \%$ glucose and grown at $30^{\circ} \mathrm{C}$ overnight in an orbital shaker. Cells were pelleted, and the supernatant-containing phages were collected for analysis in phage ELISA. Briefly, microtiter plates (Nunc, Roskilde, Denmark) were coated with $100 \mu \mathrm{L} /$ well of $0.05 \mathrm{M}$ carbonate-bicarbonate buffer ( $\mathrm{pH}$ 9.6) containing $5 \mu \mathrm{g} / \mathrm{mL}$ of rabies purified antigen and incubated overnight at $4^{\circ} \mathrm{C}$. Blocking was performed using 2\% bovine gelatin for $1 \mathrm{~h}$ at $37^{\circ} \mathrm{C}$ using PBS-T followed by incubation with phages at a concentration of $10^{11} / 100 \mu \mathrm{L}$ of bacterial supernatant/well for $2 \mathrm{~h}$ at $37^{\circ} \mathrm{C}$. Background noise was estimated using nonspecific phages in an uncoated microtiter plate. Binding of the phage particles to antigen was detected with the horseradish peroxidase-(HRP-)conjugated anti-M13 mouse antibody (Pharmacia Biotech, dilution 1:5000) and followed by $3,3^{\prime}, 5,5^{\prime}$ tetramethylbenzidine (TMB). The plate was incubated at $37^{\circ} \mathrm{C}$ for $10 \mathrm{~min}$, and the reaction was stopped by addition of $1.25 \mathrm{M} \mathrm{H}_{2} \mathrm{SO}_{4}$. The absorbance was measured at $450 \mathrm{~nm}$ using a microplate reader (BIO-TEK, USA).
2.9. Restriction Mapping and Sequence Analysis. The diversity of the selected recombinant clones was checked by am-plifying the $\mathrm{scFv}$ insert using primers light forward (LB) and heavy chain reverse (HF) followed by digestion with restriction enzyme BstNI. The banding pattern of the restriction digestion was analyzed by $3 \%$ agarose gel electrophoresis. Phagemid DNA was isolated using Qiagen miniprep kit. Each scFv construct was sequenced using S1 and S6 sequencing primers (Amersham Biosciences, USA). Nucleotide sequence was determined using the standard protocols from Big Dye Terminator v3.1 cycle sequencing kit (Applied Biosystems, USA) in conjunction with AB3130XL automated genetic analyzer (Applied Biosystems, USA). The sequences were analyzed by using IMGT/ V-QUEST software [18].

2.10. Expression and Purification of Soluble Antibody Fragments. Phages, which showed reactivity with rabies virus were used to isolate plasmid DNA with a commercial kit. The scFv was amplified with primers containing EcoRI and Not I sites at $5^{\prime}$ and $3^{\prime}$ ends, gel purified, and cloned into bacterial expression vector pET $20 \mathrm{~b}$ and transformed into E. coli BL21 (DE3) cells. ScFv production was induced by addition of $1 \mathrm{mM}$ isopropyl- $\beta$-D-thiogalactopyranoside (IPTG) and incubated for $4 \mathrm{~h}$ at $30^{\circ} \mathrm{C}$. The bacterial pellet was collected by centrifugation at $5000 \times \mathrm{g}$ for $20 \mathrm{~min}$ at $4^{\circ} \mathrm{C}$, resuspended in lysis buffer and sonicated. The supernatant was purified by immobilized metal affinity chromatography (IMAC). An IMAC column $(5 \mathrm{~mL})$ was equilibrated with 10 column volumes of $50 \mathrm{mM}$ Tris- $\mathrm{HCl}, 155 \mathrm{mM} \mathrm{NaCl}, \mathrm{pH}$ 7.6 (equilibration buffer). The supernatant was loaded to the column at a flow rate of $1 \mathrm{~mL} / \mathrm{min}$ and washed with 20 column volumes of washing buffer containing equilibration buffer with $30 \mathrm{mM}$ imidazole, $\mathrm{pH}$ 7.6. Bound scFv was eluted with 5 column volumes of elution buffer containing equilibration buffer with $300 \mathrm{mM}$ imidazole, $\mathrm{pH}$ 7.6, as fractions of $1 \mathrm{~mL}$ each. Purified protein was dialysed extensively against PBS. Protein concentration was deter-mined by the BCA assay kit (Sigma, USA) and stored at $-20^{\circ} \mathrm{C}$ till further use.

2.11. Electrophoresis and Immunoblot Analysis. The purified $\mathrm{scFv}$ was electrophoresed on a $12 \%$ SDS-PAGE [19]. The separated proteins were transferred to a PVDF membrane (Hybond-C, Amersham Biosciences, USA) using transblot apparatus (Bio-Rad, USA) following manufacturer's instructions. The blot was probed with His-probe (Pierce, USA) and developed using $0.05 \%$ of DAB (Sigma, USA) and $0.03 \%$ hydrogen peroxide in PBS.

2.12. Determination of Specificity of the scFv A11 against $P V$ GP. The specificity was determined by (a) immunoblot transfer assay, (b) Sandwich ELISA to determine the reactivity of A11 towards PV GP, (c) Competitive ELISA to assess the competition of A11 with monoclonal M5B4, and (d) Binding specificity of A11 to unrelated viruses. All the procedures were done as described by Sridevi et al. [20]. 
2.13. Epitope Mapping of A11 Fragment. The A11 antibodybound epitope was mapped with a constrained phage display peptide library of random peptide 7 mers fused to a minor coat protein (pIII) of M13 phage. Maxisorp Immunotube (Nunc, Denmark) was coated overnight at $4^{\circ} \mathrm{C}$ with purified A11 (50 ng/well) diluted in $0.1 \mathrm{M} \mathrm{NaHCO}_{3}(\mathrm{pH}$ 8.6). The tubes were washed with PBS-T 5 times and incubated for $2 \mathrm{~h}$ at $4^{\circ} \mathrm{C}$ with blocking buffer, $1 \%$ BGPBS-T. The tube was washed as mentioned above and incubated with $4 \times 10^{10}$ of constrained Ph.D.-C7C peptide phage library (New England Biolabs) at room temperature for $2 \mathrm{~h}$. The tube was washed and bound phages were eluted by disrupting the binding interactions with $0.2 \mathrm{M}$ glycine ( $\mathrm{pH} 2.2), 1 \mathrm{mg} / \mathrm{mL}$ BSA, and neutralized with $1 \mathrm{M}$ Tris- $\mathrm{HCl}(\mathrm{pH}$ 9.1). The bound phages were subjected to three rounds of biopanning as mentioned above, and the eluted phages from third round were titrated by infecting E. coli strain ER2738. The clones obtained after the final round of panning/titrations were sequenced, and analysis of aminoacid sequence of the presented peptide was deduced to determine the consensus-binding motif.

2.14. Amplification of Glycoprotein Gene and Cloning into pGEX 4T1. To determine the binding site of A11 in PV GP, the glycoprotein gene was truncated and amplified as five different gene products, namely, E1, E2, E3, E4, and E5, (Table 2(a)) using gene specific primers and PCR (Table 2(b)). E1-E5 and pGEX $4 \mathrm{~T}_{1}$ were digested using the restri-ction enzymes BamHI and EcoRI according to the manufacturer's instructions (New England Biolabs, MA, USA) and purified using a gel purification kit. $\sim 45 \mathrm{ng}$ of each of the digested epitope fragments E1-E5 were ligated into $\sim 100 \mathrm{ng}$ of digested pGEX $4 \mathrm{~T}_{1}$ vector in a total volume of $20 \mu \mathrm{L}$ using T4 DNA ligase, and the ligated products were transformed into chemically competent $E$. coli strain of TOP 10 cells. The plates were incubated overnight at $37^{\circ} \mathrm{C}$ and individual colonies were picked from each plate, inoculated into the medium containing ampicillin, and grown at $37^{\circ} \mathrm{C}$ in an orbital shaker for overnight. The overnight grown culture was used for isolation of plasmids using plasmid mini-prep kit from QIAGEN, and positive clones were confirmed by restriction double digestion and sequence analysis.

\subsection{Expression and Purification of Glycoprotein Epitope} Genes. pGEX $4 \mathrm{~T}_{1}$ E1-E5 plasmids were transformed into BL21 (DE3) cells of E. coli strain. Individual colonies were picked, and each of the culture expressing epitopes E1-E5 regions of glycoprotein was induced by addition of $1 \mathrm{mM}$ IPTG and incubated for $4 \mathrm{~h}$ at $30^{\circ} \mathrm{C}$. The bacterial pellet was collected by centrifugation at $5000 \times \mathrm{g}$ for $20 \mathrm{~min}$ at $4^{\circ} \mathrm{C}$ and resuspended in lysis buffer and sonicated. The supernatant was purified by glutathione agarose column. Purified protein was dialysed extensively against PBS. Protein concentration was determined by the BCA assay kit (Sigma, USA) and stored at $-20^{\circ} \mathrm{C}$ for further characterization.

2.16. Indirect ELISA for Epitope Specificity. A microtiter plate (Nunc, Denmark) was coated with $100 \mathrm{ng} /$ well of E1-E5 in

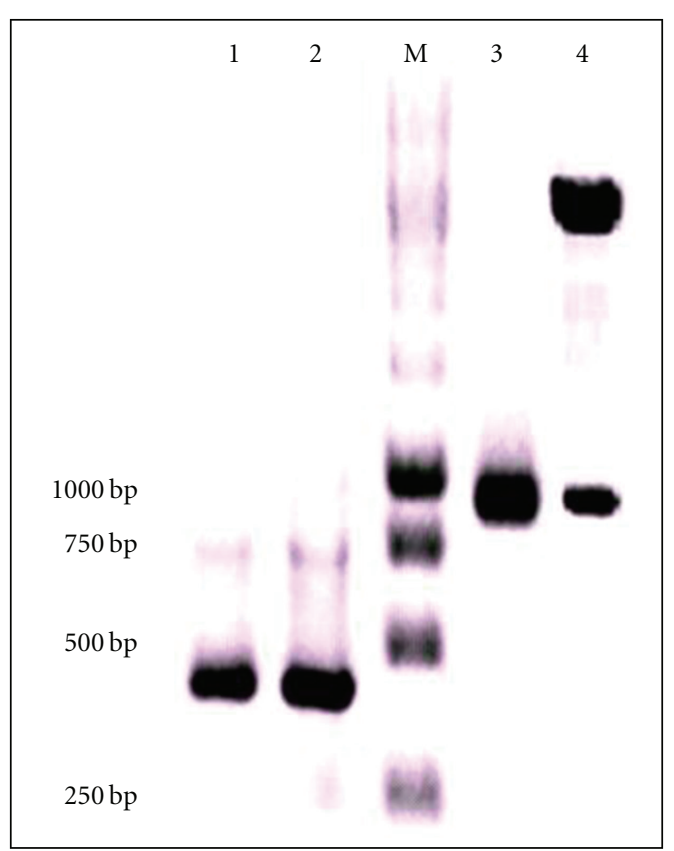

Figure 1: Agarose gel electrophoresis analysis of PCR-amplified products from immunized splenocytes. Lane $M$ shows the DNA ladder and Lanes 1, 2, and 3 show the variable heavy, variable light chain genes, and assembled PCR products, respectively. Lane 4 is the recombinant expression cassette after NcoI and NotI digestion showing release of scFv product.

$50 \mathrm{mM}$ carbonate-bicarbonate buffer ( $\mathrm{pH}$ 9.6), respectively, and incubated overnight at $4{ }^{\circ} \mathrm{C}$. The plate was washed thrice with PBS-T and blocked with $1 \%$ BGPBS-T followed by washing with PBS-T. $20 \mathrm{ng} / 100 \mu \mathrm{L}$ of A11 was added in the first well, serial diluted, and incubated at $37^{\circ} \mathrm{C}$ for $1 \mathrm{~h}$. The plate was washed five times with PBS-T and dried. The binding of the A11 with different epitopes of PV GP was detected by addition of His-probe and a chromogenic substrate TMB. The reaction was stopped by addition of $1.25 \mathrm{M} \mathrm{H}_{2} \mathrm{SO}_{4}$, and the absorbance was measured at $450 \mathrm{~nm}$ using a microplate reader (BIO-TEK, USA). The experiment was done in triplicates to evaluate the concentration-dependent binding activity of A11 towards different epitopes of PV GP.

\section{Results}

3.1. Amplification and Cloning of VH and VL Genes to Form scFv Phage Display Cassette. Total RNA was isolated from immunized mice spleen cells and CDNA was synthesized. The cDNA was used as a template for the PCR amplification of the VH and VL genes by using universal primers (Table 1), which yielded a $321 \mathrm{bp}$ and $303 \mathrm{bp}$ amplicon as shown in Figure 1, Lanes 1 and 2, respectively. The resultant VH and VL were assembled into a single chain fragment using a peptide linker $\left(\mathrm{Gly}_{4} \mathrm{Ser}\right)_{3}$ using SOE PCR which could be visualized as a $750 \mathrm{bp}$ amplicon on the agarose gel as shown in Figure 1, Lane 3. The scFv was digested by NcoI/Not I and ligated into the phage display vector PCANTAB $5 \mathrm{E}$ to form the cassette yielding a library of $4.2 \times 10^{7} \mathrm{pfu} / \mathrm{mL}$. The 
TABle 2: (a) Location of selected epitopes present on PV GP and its size in base pairs (bp). (b) Primers used for amplification of epitope coding regions of PV GP and cloning into pGEX vector.

(a)

\begin{tabular}{lcc}
\hline Epitope gene ID & Location on PV GP & Size in bp \\
\hline E1 & $3318-3640$ & 322 \\
E2 & $3641-3888$ & 247 \\
E3 & $3889-4134$ & 238 \\
E4 & $4135-4380$ & 245 \\
E5 & $4381-4697$ & 316 \\
\hline
\end{tabular}

(b)

\begin{tabular}{ll}
\hline Epitope 1 For & ATCGGGATCCGGAGTATTTTTCAATGGTATAAT \\
Epitope $1 \mathrm{Rev}$ & ATCGGAATTCTCCTCTGAGATTGTGTTGT \\
Epitope 2 For & ATCGGGATCCGGAGTATTTTTCAATGGTATAAT \\
Epitope 2 Rev & ATCGGAATTCCCGTTCGTGCACATCG \\
Epitope 3 For & ATCGGGATCCAAGAACGGTGACGAGG \\
Epitope 3 Rev & ATCGGAATTCCCGTTCGTGCACATCG \\
Epitope 4 For & ATCGGGATCCCAGCAACATATGGAGTTGT \\
Epitope 4 Rev & ATCGGAATTCCAAGGCAGTCAGGGCC \\
Epitope 5 For & ATCGGGATCCTGCCCAAACAATTTGGTA \\
Epitope 5 Rev & ATCGGAATTCCCCGTTCATTTTTATGGC \\
\hline
\end{tabular}

presence of scFv in the library was analyzed by NcoI/NotI digestion as shown in Figure 1, Lane 4.

3.2. Selection of Phage Displaying Antirabies Recombinant Antibodies by Biopanning. An scFv phage display library containing $1 \times 10^{12} \mathrm{pfu} / \mathrm{mL}$ of independent clones was subjected to biopanning for selection of scFvs against PV GP. Enrichment of antigen-specific binding phage was measured by performing the three rounds of panning, which resulted in $1 \times 10^{3}, 1 \times 10^{5}$, and $1 \times 10^{9}$ pfu of eluted phage in first, second and third rounds of panning, respectively. Antigen-binding activity of the pooled phages from each round of the panning was analyzed by phage ELISA, resulting in the successful en-richment of rabies-virus-specific binders as shown in Figure 2. Eluted phages from round 3 were used to infect $E$. coli TG1 to produce phage antibodies, and the supernatants containing phage antibodies from 96 individual clones were tested by phage ELISA against PV GP, to select antigenspecific phage scFvs. Of the 96 clones tested, 30 showed positive binding to rabies virus. PCR analysis confirmed that the selected clones contained an insert corresponding to the size of an scFv fragment. DNA sequence analysis of two strongest binding clones, A11 and D11, showed similar VH and VL sequences. All further studies were done using A11.

3.3. DNA Fingerprint Analysis Using Restriction Fragment Length Polymorphism (RFLP). To determine the diversity of the library, PCR-amplified scFv fragments from 30 individual clones of $s c F v$ library were analyzed by $B s t \mathrm{NI}$ fingerprinting. Each $\mathrm{scFv}$ showed a different digestion pattern indicating variations in Bst NI recognition sites confirming diversity amongst randomly selected clones. To confirm that the scFvs consisted of $\mathrm{VH}$ and VL chains of immunoglobulin molecules and to further analyze library diversity, DNA sequence analysis was performed on 30 randomly selected clones obtained from an scFv library. All $s c F v$ sequences were analyzed using the web-based NCBI Ig BLAST program (http://www.ncbi.nlm.nih.gov/igblast/) and IMGT/V-QUEST software to approximate framework and complementarity determining regions. In the library sequenced, the majority of VH and VL chains had open reading frames encoding full-length VH and VL chains (data not shown).

3.4. Expression and Purification of Soluble scFv A11. Sequence analysis of $\mathrm{scFv} A 11$ by International ImmunoGeneTics information system (IMGT) revealed the presence of 223 amino acids as shown in Figure 3. ScFv A11 was transformed into E. coli BL21 (DE3) for production of soluble scFv for further characterization. The purified protein eluted fraction of $\mathrm{scF}$ shows a $\sim 28 \mathrm{kDa}$ band on both SDS-PAGE and immunoblot analysis as indicated in Figure 4.

3.5. Reactivity of A11 with Rabies Virus Glycoprotein. Immunoblotting of $\mathrm{A} 11$ and M5B4 against the rabies virus structural proteins resolved in a $10 \%$ gel by nonreducing SDS-PAGE clearly indicated binding to a $\sim 66 \mathrm{kDa}$ protein corresponding to PV GP as indicated in Figure 5. The PVNP-specific MAb-N5G4 was used as a negative control and it bound to a $\sim 55 \mathrm{kDa}$ protein corresponding to rabies virus nucleoprotein (PV NP).

3.6. Sandwich ELISA. Sandwich ELISA was performed to determine the reactivity of the A11. Titration of the PV GP 


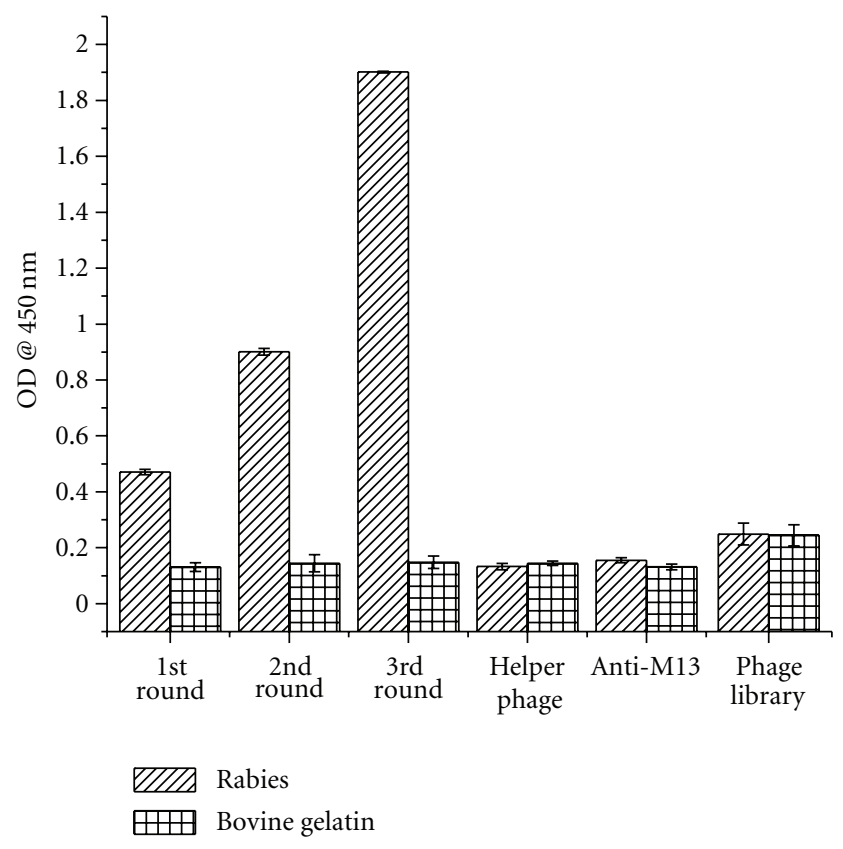

FIGURE 2: Phage ELISA showing the enrichment of phages specific for rabies virus glycoprotein during the panning cycles. After each round of panning, the output phages were added to microtiter wells with $200 \mathrm{ng}$ of PV GP or bovine gelatin. Anti-M13 and helper phage was used as a control to check the back ground value. Bound phages were detected by horseradish peroxidase (HRP) conjugated antiM13 antibody.

\section{EFGYQMTQTTSSLSASLRDRVTISCRASQDITNYLNWYQQKPDGTVK}

\section{LLIYYASNLHSGVPSRFSGSGSGTDYSLTISNLEPEDIATYYCQCSKVP}

\section{YTFGGGTKLEIKRGGGGSGGGGSGGGGSQVQLQQSGAELVRPKDYY}

\section{MHWVKQRPEQGLEWIGRIDPENGNTKYDPKFQGKATITADTSSNTA}

\section{YSLQLSSLTSEDTAVYYCARGGAMDYWGQGTSVTVSSAAA}

Figure 3: Amino acid sequence of anti-rabies mouse scFv containing VL, linker peptide and VH. The linker peptide is marked in italics. The restriction enzyme sites for cloning of the $\mathrm{scFv}$ gene are underlined.

against a constant dilution of A11 revealed a concentrationdependent reduction of the binding signal as shown in Figure 6. The control showed no reactivity in ELISA indicating the specificity of the A11.

3.7. Competitive ELISA to Determine Site Specificity of A11. Competitive ELISA was performed to determine the competition between M5B4 [21] and the A11 for the same site on PV GP. No competition as detected when the constant amount of M5B4 was allowed to compete with varying twofold dilutions of A11. There was no change in the optical density following the dilution of the A11 indicating that it did not compete for the same site on PV GP as shown in Figure 7. Antirabies diabody was used as a positive control [20].

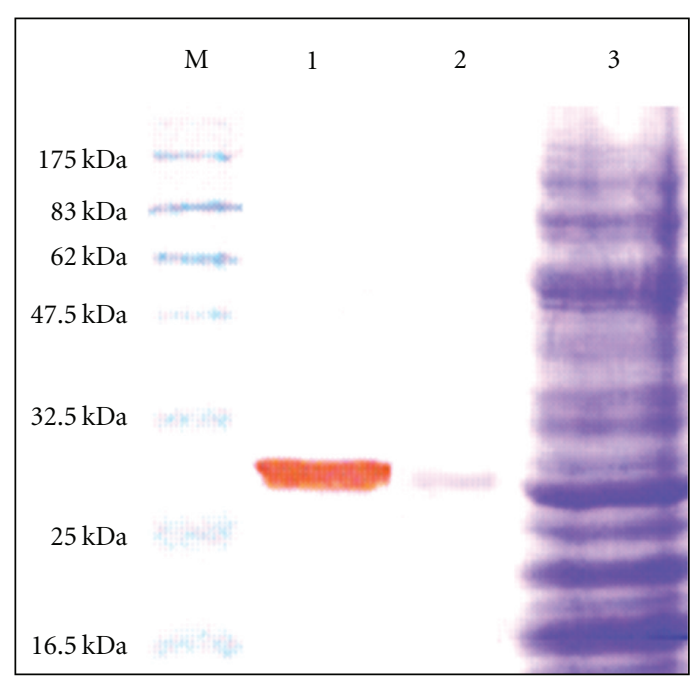

FIgURE 4: Detection of recombinant A11 on 12\% sodium dodecyl sulphate-polyacrylamide gel electrophoresis. Lane $\mathrm{M}$ shows protein molecular size standard. Lane 1 is a purified protein transferred onto PVDF membrane and probed with His-probe and developed using DAB substrate. Lanes 2 and 3 are a purified protein and crude lysate stained with coomassie brilliant blue R-250.

3.8. Cross Reactivity of A11 to Unrelated Proteins. Antigen specificity of the A11 was verified by reactivity in ELISA against hepatitis $\mathrm{A}$, hepatitis $\mathrm{B}$, and chikungunya viruses. The comparison of the absorbance values, as shown in Figure 8, indicated that A11 reacted only with rabies virus in a concentration-dependent manner and showed no reactivity towards other viruses.

3.9. Epitope Mapping. A constrained heptapeptide library displayed on filamentous phage was screened on coated scFv A11. Following four rounds of panning/selection, 10 clones were selected of which 7 bound to the same constrained heptapeptide (SGPSYTT). A sequence similarity between the constrained peptide recognized by $\mathrm{A} 11$ and the conformational antigen site II of PV GP at nucleic acid sequence 3489-3503 (SGFSY) strongly suggested that A11 bound to the antigenic site II of PV GP.

3.10. Amplification of Various Regions of the Glycoprotein Gene and Cloning into pGEX 4T1. PV GP was used as a template for the PCR amplification $\left(94^{\circ} \mathrm{C}\right.$ for $1 \mathrm{~min}, 50^{\circ} \mathrm{C}$ $1 \mathrm{~min}, 72^{\circ} \mathrm{C} 1 \mathrm{~min}$, for 34 cycles) of the epitope regions (E1, E2, E3, E4 and E5) (Table 2(a)) by respective gene-specific primers (Table 2(b)) yielded $322 \mathrm{bp}, 247 \mathrm{bp}, 238 \mathrm{bp}, 245 \mathrm{bp}$, and $316 \mathrm{bp}$ amplicons, respectively (data not shown). The resultant epitope regions were digested with BamHI and EcoRI and ligated into the bacterial expression vector pGEX $4 \mathrm{~T}_{1}$ to yield pGEX $4 \mathrm{~T}_{1} \mathrm{E} 1-\mathrm{E} 5$.

3.11. Expression and Purification of Glycoprotein Epitope Regions. pGEX $4 \mathrm{~T}_{1}$ E1-E5 containing glycoprotein epitopes (E1-E5) was transformed into BL21 (DE3) cells and was expressed by induction with $1 \mathrm{mM}$ IPTG. The cell pellet was 


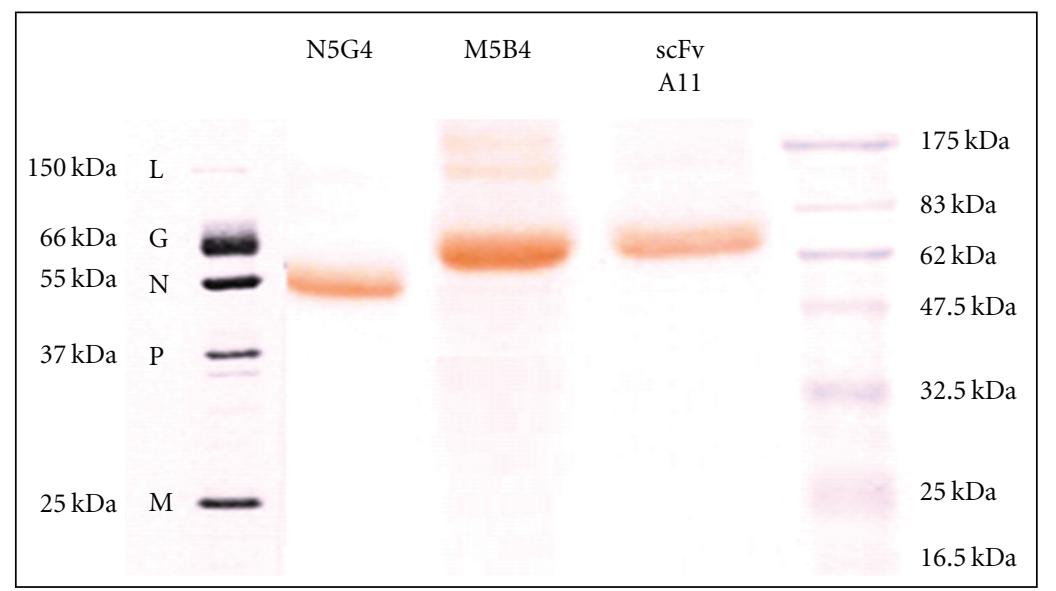

FIGURE 5: Reactivity of the A11 with the rabies virus glycoprotein in immuno-transfer blot analysis. Lane N5G4 was developed using antibody specific to nucleoprotein of rabies virus. Lane M5B4 was developed using antibody specific to glycoprotein site III of rabies virus. Lane A11 was developed using A11 specific to glycoprotein of rabies virus. Lane M shows protein molecular size standard.

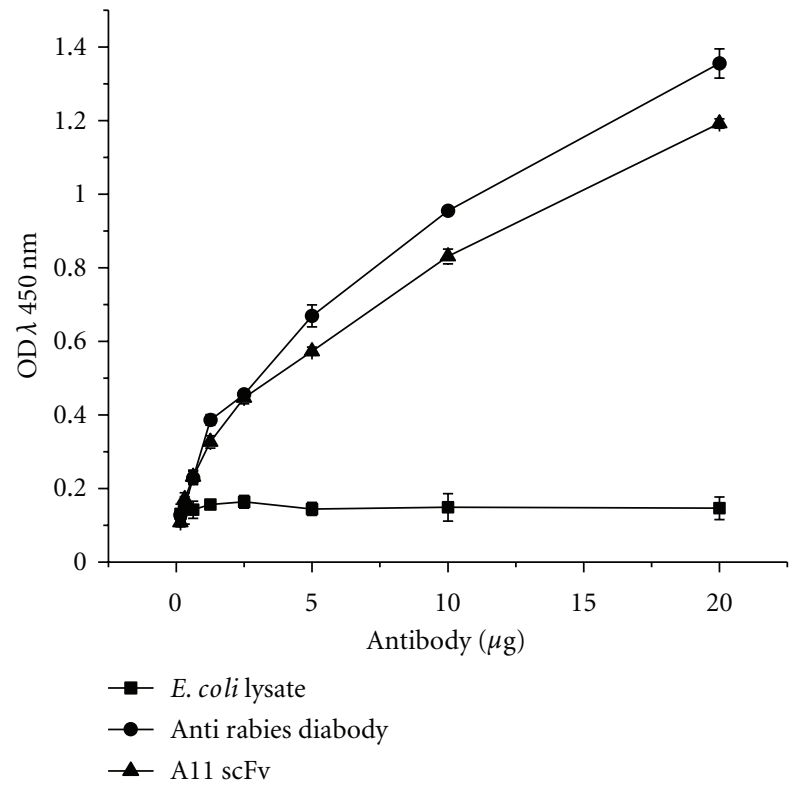

FIGURE 6: Analysis of antigen binding affinity of A11 by ELISA to evaluate the activity of A11 to rabies virus glycoprotein. Negative control used for ELISA is E. coli lysate, and positive control is antirabies diabody.

lysed, and the cytoplasmic fraction was purified on a glutathione agarose column. Analysis of the purified GST fusions E1-E5 by coomassie staining and immunoblotting (data not shown) indicated the presence of a $38,35,35,35$, and $37 \mathrm{kDa}$ bands, respectively. The yield of glycoprotein epitope regions E1-E5 ranged from 1.8 to $2.0 \mathrm{mg}$ /liter of culture.

3.12. Indirect ELISA for Epitope Specificity. Indirect ELISA was performed to determine the specificity of A11 towards E1-E5. Titration of the A11 against a constant dilution of different polypeptides of PV GP revealed a concentrationdependent reduction of the binding signal in the wells coated

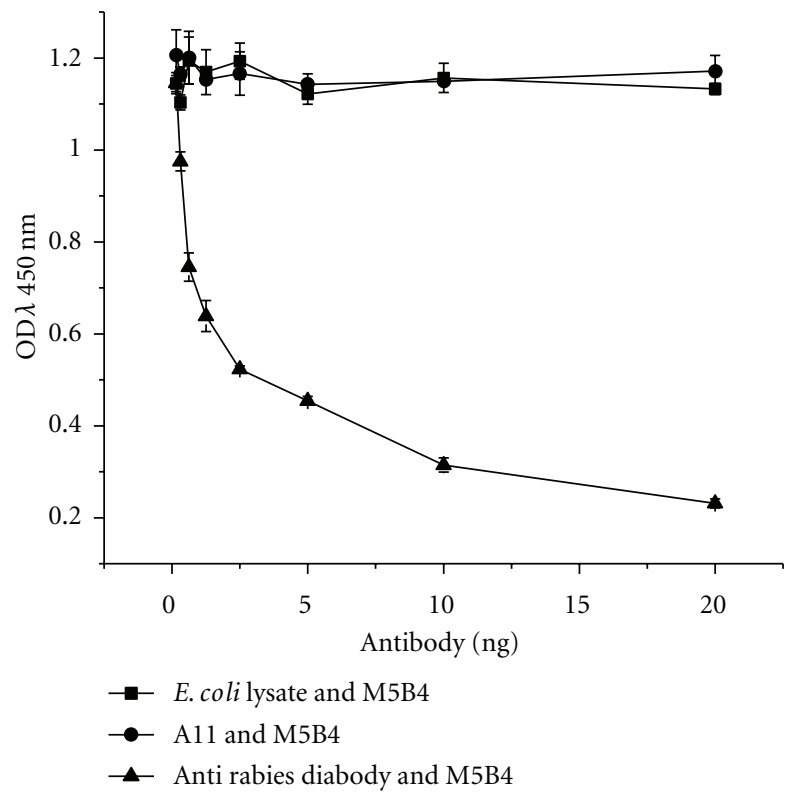

FIgure 7: Competitive ELISA using the A11 and the RV GP-specific human antirabies diabody and mouse Mab M5B4 specific for site III.

only with E1 as shown in Figure 9, indicating that A11 binds strongly with E1 epitope, which codes for the aminoacid sequence SGFSY present in the antigenic site II of PV GP.

\section{Discussion}

Antibody engineering using phage display technology [22] allowed the expression of scFvs on the surface of bacteriophage [12] thereby offering several advantages over hybridoma technology which included generation of antibodies with increased affinity and specificity by mimicking affinity maturation in normal immune system. This provided 


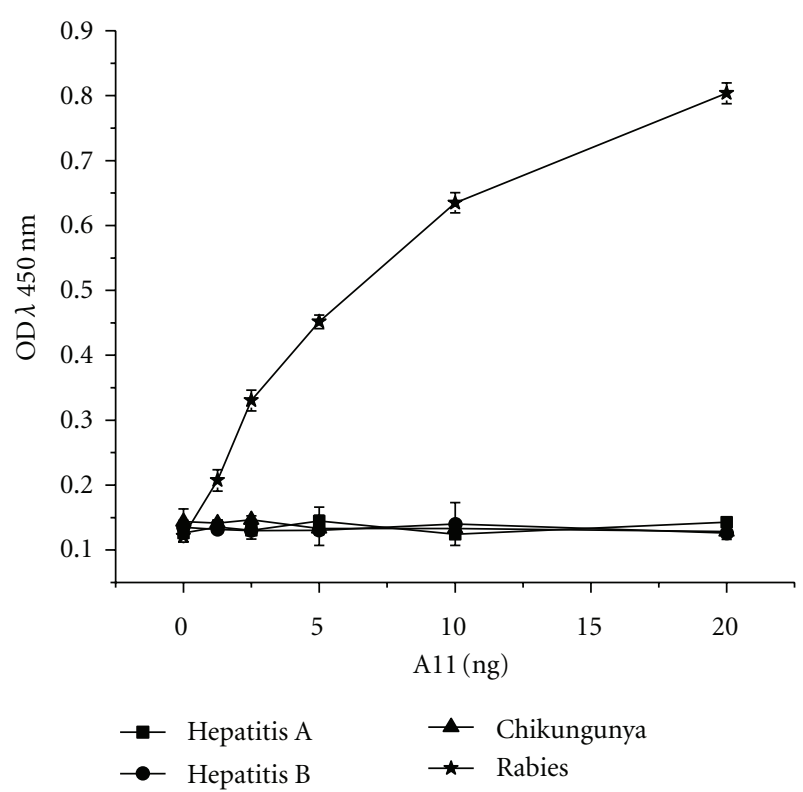

FIgURE 8: ELISA-based comparison of A11 (at different concentrations) binding to unrelated viruses showing that the antibody binds to rabies virus and does not show any reactivity to Hepatitis A virus (HAV), Hepatitis B surface antigen (HB), and Chikungunya virus (CHIKV). The data shown are the representative of three similar experiments and are the mean of triplicate samples.

an antibody with a stable genetic source, which could be easily manipulated allowing their usage in various clinical diagnosis and therapeutic applications [23-28]. An enormous number of antibody fragments (upto $10^{9}$ clones) could be isolated from a single immunized animal, and the affinity of these antibodies could be increased by in vitro affinity maturation $[29,30]$.

In this study, we constructed an scFv library from murine splenocytes, which was directed against the PV GP using phage display technology. scFvs were expressed on the phage as membrane-anchored proteins, which allowed us to perform antibody selection very efficiently and further allowed the isolation of the best candidate through biopanning. Following three rounds of biopanning, 30 PV GP positive phage clones were selected by phage ELISA of which only 2 clones elicited a very strong signal in ELISA. DNA sequencing of these clones identified them as variable antibody genes belonging to the IgG1 subgroup and showed $100 \%$ similarity in their sequences. One was selected for further studies.

The scFvs are expressed on the phage surface fused to the minor coat protein III, separated by an amber codon in TG1 strain of Escherichia coli, which facilitated numerous cycles of selection and infection. To achieve optimum expression of A11 as a soluble product, phagemid isolated from positive clones were amplified with primers containing restriction sites, and the resultant PCR product was cloned into a bacterial expression vector pET $20 \mathrm{~b}$. Expression in E. coli resulted in the expression of a soluble $\sim 28 \mathrm{kDa}$ protein $\mathrm{A} 11$, which was purified to $\sim 90 \%$ homogeneity using IMAC. Purification of the bacterial lysate resulted in the yield $\sim 4 \mathrm{mg}$ of purified A11/liter of culture with a homogeneity

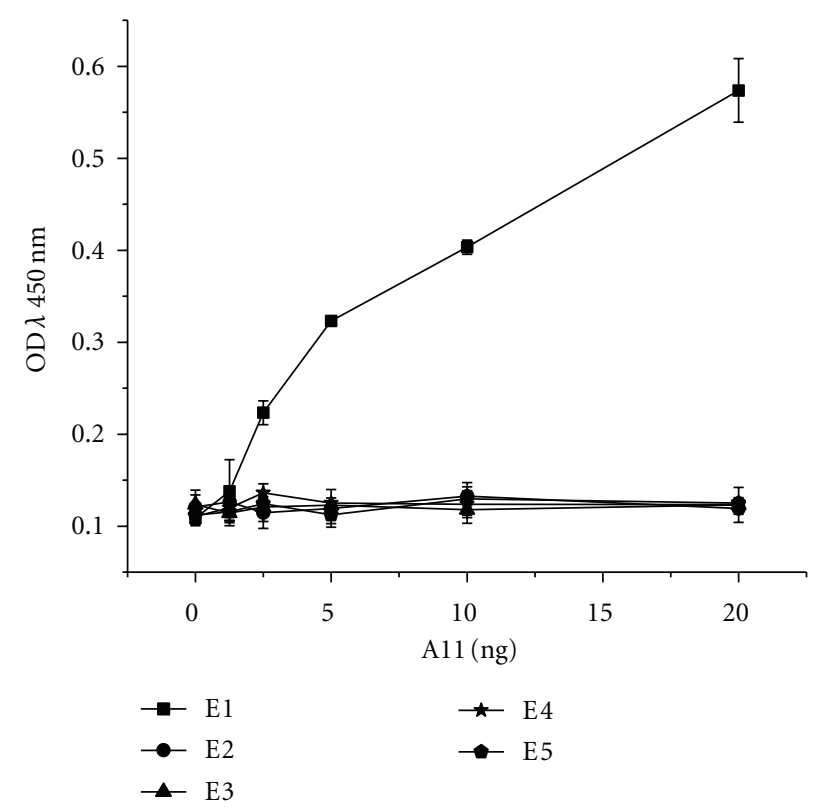

Figure 9: Analysis of epitope-binding affinity of A11 by ELISA to evaluate the activity of A11 to rabies virus glycoprotein epitopes. The data shown are the representative of three similar experiments and are the mean of triplicate samples.

of $\sim 90-95 \%$. The ease of purification reiterated the fact that expression of a functional recombinant antibody in bacteria offered many advantages over the maintenance of a hybridoma cell line, which included minimal batch-to-batch variation, ease of scale up, and so forth, at a reasonable cost. The binding of A11 to PV GP in ELISA indicated proper folding of the protein following expression. A11 binding to PV GP was demonstrated by western blot analysis. Specificity study showed that the A11 reacted only with PV GP but not with other viruses as indicated by sandwich ELISA. A11 did not compete with M5B4 for binding to PV GP, suggesting that A11 and M5B4 bound to different epitopes.

A large number of other researchers have mapped the various antigenic sites using mutational analysis on the glycoprotein of MAb-resistant variants [31-35], and they include antigenic site I located at aa 231 [36], antigenic site II, which is a discontinuous conformational epitope comprising aa 34 to 42 and aa 198 to 200 antigenic site III which is a continuous conformational epitope at aa 330 to 338 and is involved in viral pathogenicity $[37,38]$, and antigenic site IV is known to harbor overlapping linear epitopes [39-41]. The binding site of A11 was mapped using a constrained phage display library to facilitate the chance of selecting conformational peptides, which were complementary to the A11 paratope. The disulfide-constrained heptapeptides were expressed at the $\mathrm{N}$-terminus of the pIII protein of the filamentous phage with the first cysteine preceded by an alanine residue, the second cysteine followed by short spacer (Gly-Gly-Gly-Ser), and the wildtype pIII sequence in tandem [42-44]. A11 bound to the C-SGPSYTT-C which showed sequence similarity with the PV GP site II (SGFSY) 
corresponding to the nucleic acid position 3489-3503 of the PV GP gene. Further, the binding of A11 on native PV GP was determined by expressing truncated fragments based on the known gene sequences of PV GP. Fragments of antigen gene were amplified and cloned into pGEX $4 \mathrm{~T}_{1}$ bacterial expression vector and expressed as a GST fusions E1-E5. The fragments of the antigen were expressed and purified by affinity chromatography using glutathione-agarose, which permits rapid, mild, nondenaturing, and highly selective purification of binding enzymes such as GST. An ELISA study of these purified fragments clearly indicated that the selected A11 bound to E1, which encompassed the site II of PV GP and included the site SGFSY.

In conclusion, a mouse immune scFv library was constructed from splenocytes of PV immunized mice. The constructed mouse $s c F v$ library revealed and confirmed the broad diversity by BstNI fingerprinting and DNA sequence analysis. The selected $\mathrm{scFv}$ fragment A11 was shown to bind to site II of PV GP both by the use of a constrained library and a truncated PV GP encompassing the site II. The data presented not only defined the functional aspects of the $\mathrm{scFv}$ but also reiterated the fact that this methodology could be used as a means for quick development of recombinant antibodies against rabies and other infectious diseases. The antibodies thus developed could be used not only for postexposure prophylaxis of rabies but would also allow us to address the issue of natural variation amongst rabies virus field isolates.

\section{Abbreviations}

$\begin{array}{ll}\text { cDNA: } & \text { Complementary DNA } \\ \text { DAB: } & 3,3^{\prime} \text { diaminobenzidine } \\ \text { DNA: } & \text { Deoxyribonucleic acid } \\ \text { GP: } & \text { Glycoprotein } \\ \text { OD: } & \text { Optical density } \\ \text { RNA: } & \text { Ribonucleic acid } \\ \text { RT-PCR: } & \text { Reverse transcription-polymerase chain } \\ & \text { reaction } \\ \text { scFv: } & \text { single-chain Fv antibody fragment } \\ \text { VH: } & \text { Variable heavy chain } \\ \text { VL: } & \text { Variable light chain. }\end{array}$

\section{References}

[1] J. S. Smith, "New aspects of rabies with emphasis on epidemiology, diagnosis, and prevention of the disease in the United States," Clinical Microbiology Reviews, vol. 9, no. 2, pp. 166176, 1996.

[2] D. A. Warrell and M. J. Warrell, "Human rabies: a continuing challenge in the tropical world," Schweizerische Medizinische Wochenschrift, vol. 125, no. 18, pp. 879-885, 1995.

[3] A. Casadevall, "Passive antibody administration (immediate immunity) as a specific defense against biological weapons," Emerging Infectious Diseases, vol. 8, no. 8, pp. 833-841, 2002.

[4] H. Wilde, P. Khawplod, T. Hemachudha, and V. Sitprija, "Postexposure treatment of rabies infection: can it be done without immunoglobulin?" Clinical Infectious Diseases, vol. 34, no. 4, pp. 477-480, 2002.
[5] D. M. Satpathy, T. Sahu, and T. R. Behera, "Equine rabies immunoglobulin: a study on its clinical safety," Journal of the Indian Medical Association, vol. 103, no. 4, pp. 238-242, 2005.

[6] M. A. A. Persson, R. H. Caothien, and D. R. Burton, "Generation of diverse high-affinity human monoclonal antibodies by repertoire cloning," Proceedings of the National Academy of Sciences of the United States of America, vol. 88, no. 6, pp. 24322436, 1991.

[7] G. P. Smith, "Filamentous fusion phage: novel expression vectors that display cloned antigens on the virion surface," Science, vol. 228, no. 4705, pp. 1315-1317, 1985.

[8] M. J. Feldhaus, R. W. Siegel, L. K. Opresko et al., "Flowcytometric isolation of human antibodies from a nonimmune Saccharomyces cerevisiae surface display library," Nature Biotechnology, vol. 21, no. 2, pp. 163-170, 2003.

[9] J. Hanes, L. Jermutus, S. Weber-Bornhauser, H. R. Bosshard, and A. Plückthun, "Ribosome display efficiently selects and evolves high-affinity antibodies in vitro from immune libraries," Proceedings of the National Academy of Sciences of the United States of America, vol. 95, no. 24, pp. 14130-14135, 1998.

[10] R. H. J. Begent, M. J. Verhaar, K. A. Chester et al., "Clinical evidence of efficient tumor targeting based on single-chain Fv antibody selected from a combinatorial library," Nature Medicine, vol. 2, no. 9, pp. 979-984, 1996.

[11] D. R. Burton, J. Pyati, R. Koduri et al., "Efficient neutralization of primary isolates of HIV-1 by a recombinant human monoclonal antibody," Science, vol. 266, no. 5187, pp. 1024-1027, 1994.

[12] J. McCafferty, A. D. Griffiths, G. Winter, and D. J. Chiswell, "Phage antibodies: filamentous phage displaying antibody variable domains," Nature, vol. 348, no. 6301, pp. 552-554, 1990.

[13] P. N. Nelson, G. M. Reynolds, E. E. Waldron, E. Ward, K. Giannopoulos, and P. G. Murray, "Monoclonal antibodies.," Molecular Pathology, vol. 53, no. 3, pp. 111-117, 2000.

[14] D. J. Schofield, J. Glamann, S. U. Emerson, and R. H. Pur-cell, "Identification by phage display and characterization of two neutralizing chimpanzee monoclonal antibodies to the hepatitis E virus capsid protein," Journal of Virology, vol. 74, no. 12, pp. 5548-5555, 2000.

[15] P. Holliger and P. J. Hudson, "Engineering antibody fragments and the rise of single domains," Nature Biotechnology, vol. 23, pp. 1126-1136, 2005.

[16] J. D. Marks, H. R. Hoogenboom, T. P. Bonnert, J. McCafferty, A. D. Griffiths, and G. Winter, "By-passing immunization: human antibodies from V-gene libraries displayed on phage," Journal of Molecular Biology, vol. 222, no. 3, pp. 581-597, 1991.

[17] T. Clackson, H. R. Hoogenboom, A. D. Griffiths, and G. Winter, "Making antibody fragments using phage display libraries," Nature, vol. 352, no. 6336, pp. 624-628, 1991.

[18] H. B. Lowman, S. H. Bass, N. Simpson, and J. A. Wells, "Selecting high-affinity binding proteins by monovalent phage display," Biochemistry, vol. 12, pp. 10832-10838, 1991.

[19] U. K. Laemmli, "Cleavage of structural proteins during the assembly of the head of bacteriophage T4," Nature, vol. 227, no. 5259, pp. 680-685, 1970.

[20] N. V. Sridevi, A. Shukra Madhaha, B. Neelakantam et al., "Recombinant diabody-based immunocapture enzyme-linked immunosorbent assay for quantification of rabies virus glycoprotein," Clinical and Vaccine Immunology, vol. 17, no. 8, pp. 1261-1268, 2010. 
[21] T. Nagarajan, G. S. Reddy, B. Mohana Subramanian et al., "A simple immuno-capture ELISA to estimate rabies viral glycoprotein antigen in vaccine manufacture," Biologicals, vol. 34, no. 1, pp. 21-27, 2006.

[22] W. Dall'Acqua and P. Carter, "Antibody engineering," Current Opinion in Structural Biology, vol. 8, no. 4, pp. 443-450, 1998.

[23] P. S. Chowdhury, J. L. Viner, R. Beers, and I. Pastan, "Isolation of a high-affinity stable single-chain Fv specific for mesothelin from DNA-immunized mice by phage display and construction of a recombinant immunotoxin with anti-tumor activity," Proceedings of the National Academy of Sciences of the United States of America, vol. 95, no. 2, pp. 669-674, 1998.

[24] M. Figini, L. Obici, D. Mezzanzanica et al., "Panning phage antibody libraries on cells: isolation of human Fab fragments against ovarian carcinoma using guided selection," Cancer Research, vol. 58, no. 5, pp. 991-996, 1998.

[25] Y. F. Graus, J. J. Verschuuren, A. Degenhardt et al., "Selection of recombinant anti-HuD Fab fragments from a phage display antibody library of a lung cancer patient with paraneoplastic encephalomyelitis," Journal of Neuroimmunology, vol. 82, no. 2, pp. 200-209, 1998.

[26] R. K. Sikes, W. F. Cleary, H. Koprowski, T. J. Wiktor, and M. M. Kaplan, "Effective protection of monkeys against death from street virus by post-exposure administration of tissue-culture rabies vaccine," Bulletin of the World Health Organization, vol. 45, no. 1, pp. 1-11, 1971.

[27] J. D. Watkins, G. Beuerlein, G. Pecht, P. R. McFadden, S. M. Glaser, and W. D. Huse, "Determination of the relative affinities of antibody fragments expressed in Escherichia coli by enzyme-linked immunosorbent assay," Analytical Biochemistry, vol. 253, no. 1, pp. 37-45, 1997.

[28] G. Winter, A. D. Griffiths, R. E. Hawkins, and H. R. Hoogenboom, "Making antibodies by phage display technology," Annual Review of Immunology, vol. 12, pp. 433-455, 1994.

[29] E. Gunneriusson, K. Nord, M. Uhlén, and P. Å. Nygren, "Affinity maturation of a Taq DNA polymerase specific affibody by helix shuffling," Protein Engineering, vol. 12, no. 10, pp. 873-878, 1999.

[30] S. Mao, C. Gao, C. H. L. Lo, P. Wirsching, C. H. Wong, and K. D. Janda, "Phage-display library selection of highaffinity human single-chain antibodies to tumor-associated carbohydrate antigens sialyl Lewisx and Lewisx," Proceedings of the National Academy of Sciences of the United States of America, vol. 96, no. 12, pp. 6953-6958, 1999.

[31] A. Benmansour, H. Leblois, P. Coulon et al., "Antigenicity of rabies virus glycoprotein,” Journal of Virology, vol. 65, no. 8, pp. 4198-4203, 1991.

[32] C. Prehaud, P. Coulon, F. Lafay, C. Thiers, and A. Flamand, "Antigenic site II of the rabies virus glycoprotein: structure and role in viral virulence," Journal of Virology, vol. 62, no. 1, pp. $1-7,1988$.

[33] I. Seif, P. Coulon, P. E. Rollin, and A. Flamand, "Rabies virulence: effect on pathogenicity and sequence characterization of rabies virus mutations affecting antigenic site III of the glycoprotein," Journal of Virology, vol. 53, no. 3, pp. 926-934, 1985.

[34] T. Noel, P. Olivier, E. Alain, K. Gerard, and R. Francois, "Walking along the rabies genome: is the large G-L intergenic region a remnant gene?" Proceedings of the National Academy of Sciences of the United States of America, vol. 83, no. 11, pp. 3914-3918, 1986.

[35] J. K. Scott and G. P. Smith, "Searching for peptide ligands with an epitope library," Science, vol. 249, no. 4967, pp. 386-390, 1990.
[36] M. Lafon, T. J. Wiktor, and R. I. Macfarlan, "Antigenic sites on the CVS rabies virus glycoprotein: analysis with monoclonal antibodies," Journal of General Virology, vol. 64, no. 4, pp. 843851, 1983.

[37] P. Coulon, J. P. Ternaux, A. Flamand, and C. Tuffereau, "An avirulent mutant of rabies virus is unable to infect motoneurons in vivo and in vitro," Journal of Virology, vol. 72, no. 1, pp. 273-278, 1998.

[38] B. Dietzschold, W. H. Wunner, T. J. Wiktor et al., "Characterization of an antigenic determinant of the glycoprotein that correlates with pathogenicity of rabies virus," Proceedings of the National Academy of Sciences of the United States of America, vol. 80, no. 1, pp. 70-74, 1983.

[39] H. Bunschoten, M. Gore, I. J. Claassen et al., "Characterization of a new virus-neutralizing epitope that denotes a sequential determinant on the rabies virus glycoprotein," Journal of General Virology, vol. 70, no. 2, pp. 291-298, 1989.

[40] T. R. Luo, N. Minamoto, H. Ito et al., "A virus-neutralizing epitope on the glycoprotein of rabies virus that contains Trp251 is a linear epitope," Virus Research, vol. 51, no. 1, pp. 35-41, 1997.

[41] Y. Ni, Y. Tominaga, Y. Honda, K. Morimoto, S. Sakamoto, and A. Kawai, "Mapping and characterization of a sequential epitope on the rabies virus glycoprotein which is recognized by a neutralizing monoclonal antibody, RG719," Microbiology and Immunology, vol. 39, no. 9, pp. 693-702, 1995.

[42] S. E. Cwirla, E. A. Peters, R. W. Barrett, and W. J. Dower, "Peptides on phage: a vast library of peptides for identifying ligands," Proceedings of the National Academy of Sciences of the United States of America, vol. 87, no. 16, pp. 6378-6382, 1990.

[43] F. Felici, L. Castagnoli, A. Musacchio, R. Jappelli, and G. Cesareni, "Selection of antibody ligands from a large library of oligopeptides expressed on a multivalent exposition vector," Journal of Molecular Biology, vol. 20, pp. 301-310, 1991.

[44] M. Shadidi and M. Sioud, "An anti-leukemic single chain Fv antibody selected from a synthetic human phage antibody library," Biochemical and Biophysical Research Communications, vol. 280, no. 2, pp. 548-552, 2001. 

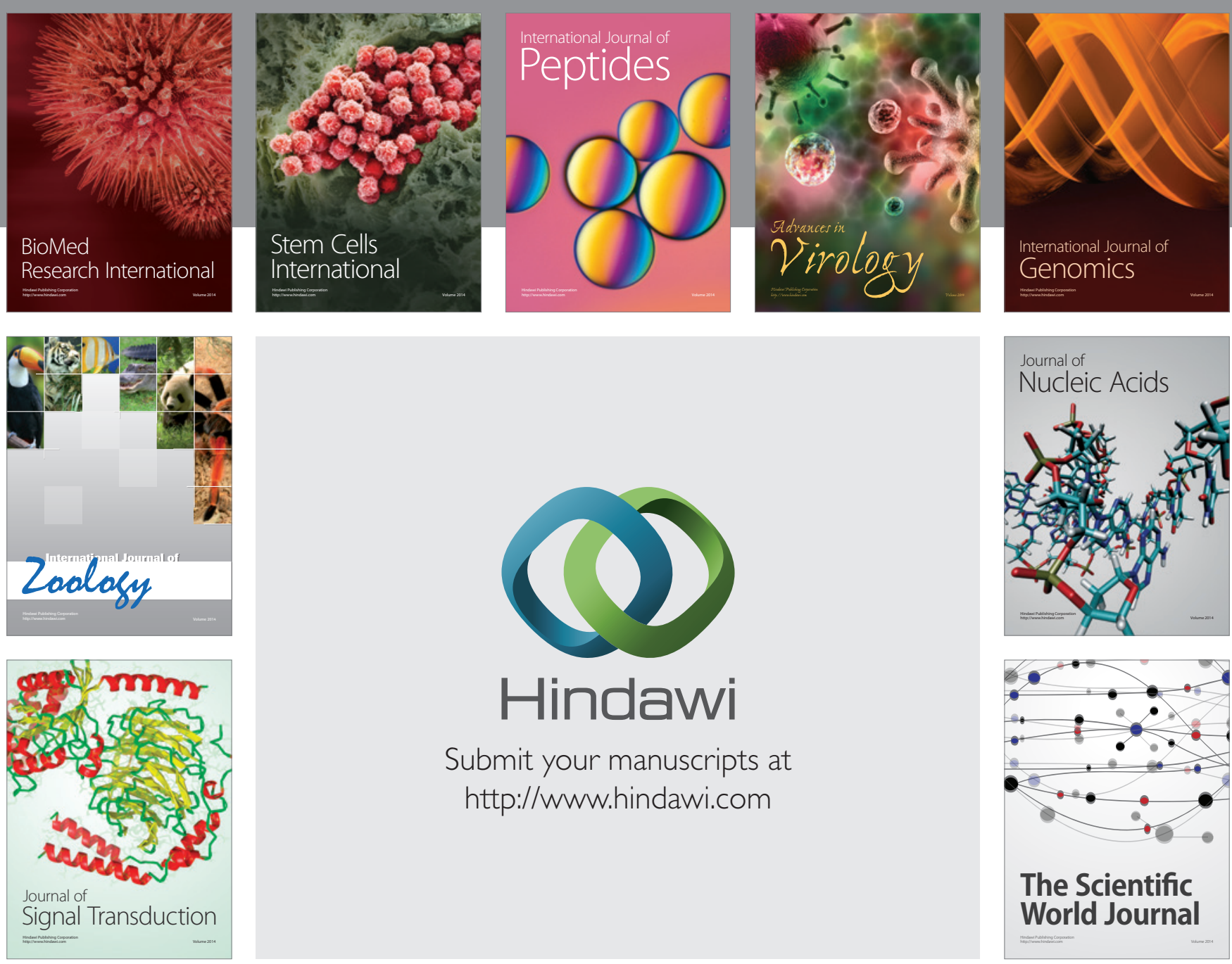

Submit your manuscripts at

http://www.hindawi.com
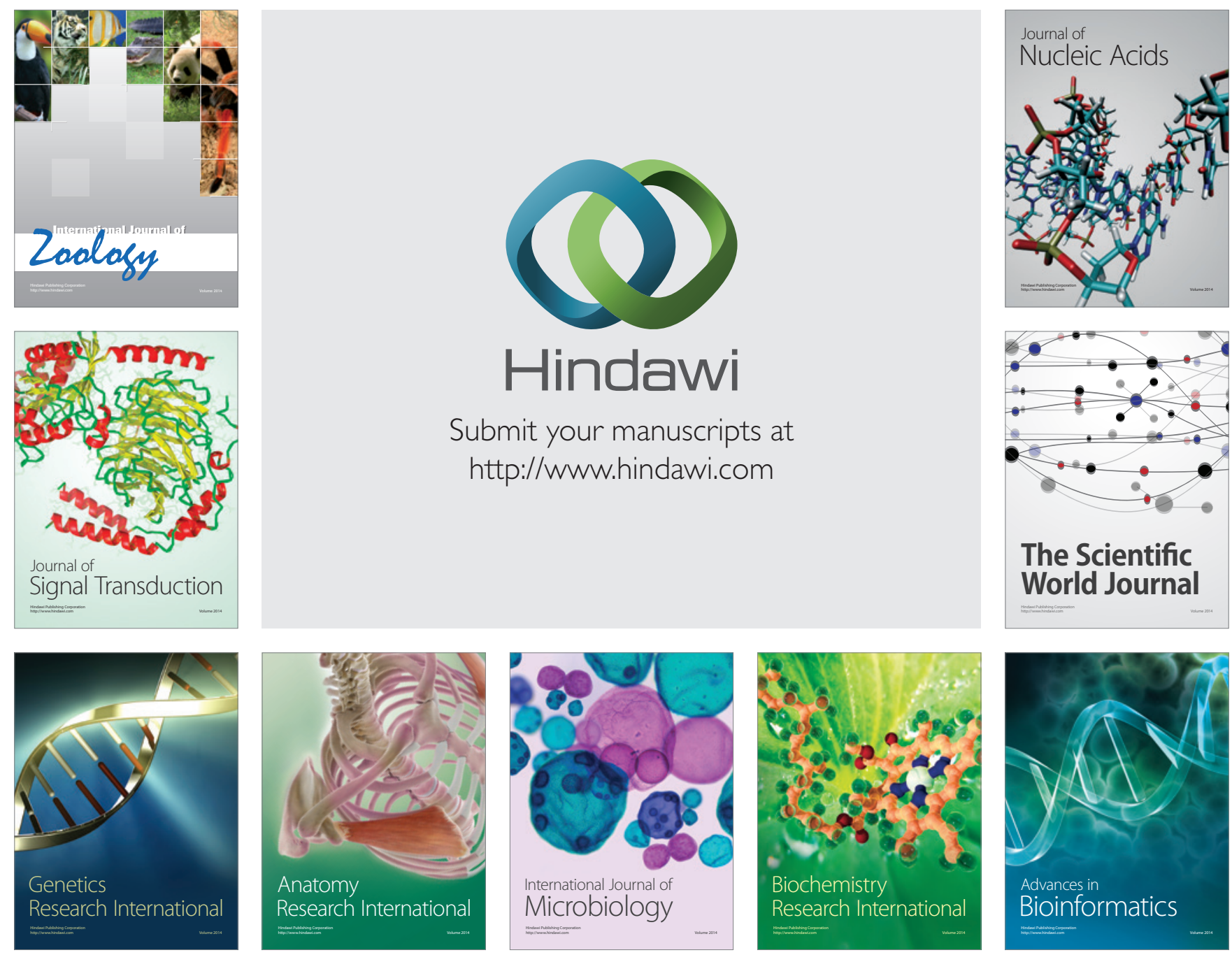

The Scientific World Journal
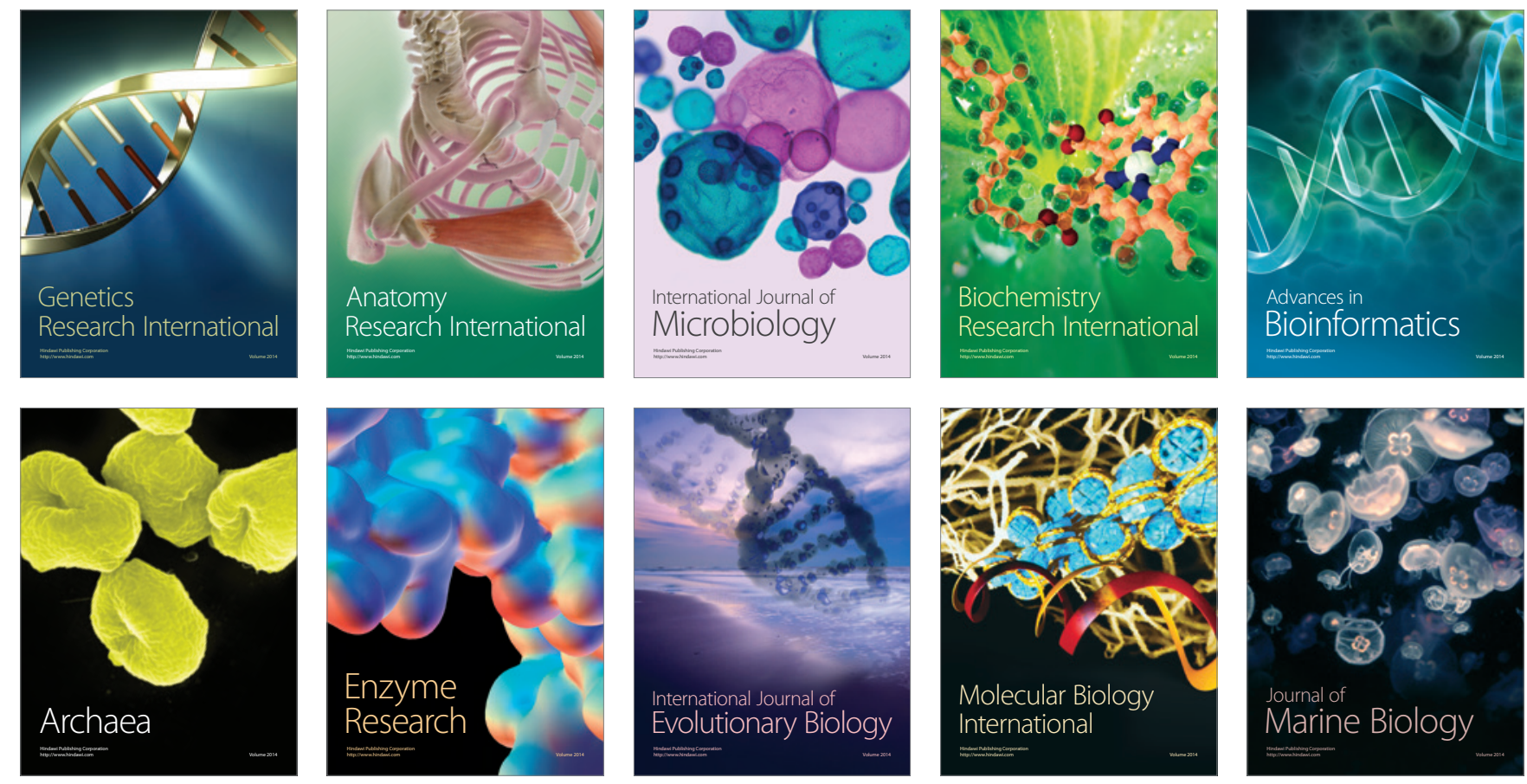